\title{
Prevalensi Penyakit Surra pada Sapi Potong di Kecamatan Cluring Banyuwangi
}

\author{
(PREVALENCE OF SURRA DISEASE IN CATTLE IN CLURING DISTRICT OF \\ BANYUWANGI REGENCY)
}

\author{
Nur Sa'adah Sulaeman'*, Agus Sunarso², Bodhi Agustono ${ }^{3}$, Poedji Hastutiek², Amung \\ Logam Saputro ${ }^{4}$, Aditya Yudhana ${ }^{2}$ \\ ${ }^{1}$ Bachelor of Veterinary Medicine, \\ ${ }^{2}$ Department of Veterinary Parasitology, \\ ${ }^{3}$ Department of Animal Husbandry, \\ ${ }^{4}$ Department of Veterinary Clinic and Animal Hospital, \\ Faculty of Veterinary Medicine, Universitas Airlangga, \\ UNAIR C-Campus Mulyorejo, Surabaya, Jawa Timur, Indonesia, 60115 \\ Telp. (031)5993016, Fax. (031)5993015 \\ *Corresponding author: nur.saadah.sulaeman-2014@fkh.unair.ac.id
}

\begin{abstract}
Abstrak
Penelitian ini bertujuan untuk menyajikan data dan informasi tentang prevalensi penyakit Surra di Kecamatan Cluring Kabupaten Banyuwangi. Penyakit Surra adalah penyakit pada ternak dan hewan liar yang disebabkan oleh Trypanosoma evansi. Jenis pemeriksaan yang dilakukan dalam penelitian ini adalah pemeriksaan parasitologis dengan ulas darah melalui pewarnaan giemsa dan metode Microhematocrit Centrifugation Technique (MHCT). Deteksi T. evansi dinyatakan positif melalui hasil pengamatan ulas darah jika nampak struktur tripomastigote dan undulating membran pada bagian posterior, sedangkan dengan uji MHCT ditunjukkan dengan adanya pergerakan dari T. evansi karena memiliki flagella bebas panjang. Hasil pemeriksaan dari 64 sampel darah sapi potong diperoleh hasil negatif. Angka prevalensi di lokasi penelitian adalah 0\%. Faktor pemicu tidak timbulnya penyakit Surra pada ternak sapi potong dilihat dari keberadaan vektor, manajemen pemeliharaan, fase infeksi T. evansi dalam tubuh host, kondisi tubuh dari host, dan waktu viabilitas T. evansi dalam sampel darah.
\end{abstract}

Kata kunci: Surra, Trypanosoma evansi, MHCT, prevalensi, sapi potong

\section{Abstract}

This study aims to present data and information about the prevalence of Surra disease in Cluring District of Banyuwangi Regency. Surra disease is a parasitic disease of most domesticated animals and some wild species caused by Trypanosoma evansi. The results of the sample were determined through the observation of the blood smear with giemsa staining and the Microhematocrit Centrifugation Technique (MHCT) method. The results of examination with blood smear were tested positively if the tripomastigote structure and undulating membrane were seen posteriorly, whereas the MHCT test was shown by the presence of T. evansi because it had flagella. The examination of the 64 blood samples of cattle obtained the negative results. The number of prevalence at the study sites was 0\%. The influence factor that Surra disease was not arisen toward cattle can be seen from the external factor such as environment condition, the existence of vector, and management of livestock raising, whereas the internal factor namely infection phase of T. evansi in the host's body, immunity of the host, and viability time of T. evansi in blood samples.

Key words: Surra, Trypanosoma evansi, MHCT, prevalence, cattle

\section{PENDAHULUAN}

Penyakit Surra merupakan penyakit pada ternak dan hewan liar yang disebabkan oleh protozoa darah Trypanosoma evansi (Dewa,
2015). Penyakit Surra disebabkan oleh protozoa darah T. evansi yang ditransmisikan secara mekanis dan nonsiklik oleh lalat penghisap darah seperti Stomoxys, Tabanus, Haematopota, Haematobia, Hippobosca, dan Chrysops (Yadav 
et al., 2016). Hewan yang sangat rentan terserang penyakit Surra adalah unta dan kuda, namun pada dasarnya semua hewan peliharaan rentan, karena $T$. evansi ditransmisikan secara mekanis oleh lalat penghisap darah dengan menggigit (Murrina, 2015). Hewan domestik yang rentan juga adalah sapi, kerbau, kambing, domba, babi, anjing, dan kucing (Fahrimal, dkk., 2013).

Penyakit Surra pada sapi dan kerbau bersifat kronis, tetapi dalam kondisi tertentu seperti kurang pakan dan hewan mengalami stres, keganasan penyakit akan meningkat dengan mortalitas hingga 80\% (Mufasirin, dkk., 2016). Penyakit Surra secara umum menunjukkan adanya gejala penurunan nafsu makan, demam, anemia, ikterus, dan kematian (Gebreyohannes and Legesse., 2014).

Dargantes et al (2009) menyebutkan gejala penyakit Surra diantaranya adalah anemia, penurunan berat badan yang signifikan, kelemahan otot, bisa terjadi abortus dan infertilitas pada kerbau, pada sapi penyakit berjalan kronis tetapi mortalitas tinggi dan bisa berlangsung selama 2 tahun, dalam fase subakut dan akut kematian bisa terjadi dalam 2 minggu 2 bulan, terjadi pembengkakan oedematous pada bagian bawah perut dan kaki, pembengkakan kelenjar limfa, dan tanda-tanda gangguan saraf seperti kepala miring, berputar - putar, dan kebutaan.

Gejala klinis yang dapat diamati umumnya hewan mengalami demam, lesu, nafsu makan berkurang, adapun pada hewan yang infeksi penyakit berjalan kronis menunjukkan anemia, kurus, bulu rontok, busung di sekitar Os mandibula dan anggota gerak kaki, dan akhirnya akan mati (Pathak and Narendra, 2005).

Kerugian ekonomi yang sangat besar, disebabkan mahalnya obat penyakit Surra, patogenitas cukup tinggi, penurunan produktivitas ternak, dan banyaknya hewan mati dengan estimasi kerugian bisa mencapai US\$ 30.000.000 (Angara et al., 2014).

Penyakit Surra pada sapi tidak patognomonis dan umumnya bersifat kronis yaitu bersifat menahun dan apabila infeksi $T$. evansi telah masuk ke dalam cairan cerebrospinal akan menunjukkan gejala saraf seperti tubuh kaku, berputar - putar, dan beberapa kasus dapat menyebabkan kematian (Derakhshanfar et al., 2010). Kematian ternak dapat disebabkan oleh anemia berat akibat infeksi T. evansi (Subekti, dkk., 2013).

Laporan kejadian Maret 2017 oleh Dinas Pertanian Kabupaten Banyuwangi bahwa populasi sapi di Kab. Banyuwangi terdapat 2 ekor yang menderita penyakit Surra di Kecamatan Cluring (Sugiyanto, 2017). Laporan kejadian tersebut meskipun tingkat kejadian masih kecil, tetapi Banyuwangi adalah wilayah endemik penyakit Surra, sehingga perlu dilakukan penelitian prevalensi penyakit Surra.

\section{METODE PENELITIAN}

Pengambilan sampel dilaksanakan di Kecamatan Cluring yaitu desa Benculuk, Cluring, Plampangrejo, dan Sembulung. Pengambilan sampel dilakukan pada tanggal 815 Januari 2018, kemudian pemeriksaan ulas darah dengan pewarnaan giemsa dilakukan di Laboratorium Instrumen Universitas Airlangga Banyuwangi. Uji MHCT dilakukan pada tanggal 9-16 Januari 2018 di Departemen Parasitologi Fakultas Kedokteran Hewan Universitas Airlangga Surabaya.

Bahan-bahan yang digunakan dalam penelitian ini adalah sampel darah sapi $3 \mathrm{ml}$, alkohol 70\%, kapas, tissue, plastisin, methanol absolut, oil emersi, dan larutan giemsa $10 \%$. Peralatan yang digunakan dalam penelitian ini adalah tabung vacutainer dengan antikoagulan EDTA ukuran $3 \mathrm{ml}$, needle vacutainer ukuran $21 \mathrm{G}$, holder vacutainer BD, objek glass, kotak preparat, giemsa stain, beker ukuran sedang, cold box, ice gell, kulkas, mikroskop olympus CX23, pipet kapiler mikrohematokrit tanpa antikoagulan (bertanda biru), hematokrit centrifugation. Jumlah sampel yang diambil dalam penelitian ini adalah 64 sampel.

Penelitian ini menggunakan metode deskriptif dengan memberikan uraian mengenai kejadian penyakit Surra pada sapi potong. Keberadaan parasit darah $T$. evansi dapat dideteksi dengan pemeriksaan parasit melalui 
metode ulas darah dengan pewarnaan giemsa dan dilakukan pula uji Microhematocrit Centrifugation Technique (MHCT). Prevalensi dihitung dari hasil positif atau negatif dari pemeriksaan sampel darah yaitu dinyatakan positif apabila terdapat protozoa darah T. evansi dalam sampel yang ditentukan melalui pengamatan dari ulas darah dengan pewarnaan giemsa dan uji MHCT. Deteksi T. evansi dinyatakan positif melalui pewarnaan giemsa jika hasil pengamatan pada mikroskop nampak struktur tripomastigote dan undulating membran pada bagian posterior, sedangkan dengan uji MHCT ditunjukkan dengan adanya pergerakan dari $T$. evansi karena memiliki flagella bebas panjang.

\section{HASIL DAN PEMBAHASAN}

Seluruh sampel menunjukkan hasil negatif berdasarkan pemeriksaan parasitologis dengan metode pewarnaan giemsa dan MHCT. Pemeriksaan secara parasitologis pada seluruh sampel menunjukkan tidak adanya $T$. evansi sehingga dinyatakan negatif artinya prevalensi kejadian penyakit Surra di Kecamatan Cluring Kabupaten Banyuwangi melalui metode pemeriksaan dalam penelitian ini adalah $0 \%$. Pengisian kuosioner dilakukan dengan observasi dan wawancara langsung kepada peternak. Hasil observasi pada sapi potong di Kecamatan Cluring secara umum menunjukkan kondisi yang baik. Beberapa sapi dengan kondisi sakit antara lain 4 ekor mengalami diare, 4 ekor mengalami gangguan reproduksi, 1 ekor ternak memiliki bulu rontok, membran serosa (kelopak mata dan lubang hidung) haemorrhage, dan 1 ekor sangat kurus. Data kuosioner tersebut ditampilkan dalam Tabel 1 berikut:

Tabel 1. Data Hasil Pemeriksaan dan Olahan Kuosioner

\begin{tabular}{|c|c|c|}
\hline No & Deskripsi & Hasil Deskripsi \\
\hline \multirow{3}{*}{1} & Kondisi Ternak & \\
\hline & 1. Sehat & $86 \%(55 / 64)$ \\
\hline & 2. Sakit & $14 \%(9 / 64)$ \\
\hline \multirow{4}{*}{2} & Bentuk Pemeliharaan & \\
\hline & 1. Intensif & $90 \%(35 / 39)$ \\
\hline & 2. Konvensional & $0 \%(0 / 39)$ \\
\hline & 3. Semi-intensif & $10 \%(4 / 39)$ \\
\hline \multirow{3}{*}{3} & Kebersihan Kandang & \\
\hline & 1. Sering dibersihkan & $75 \%(29 / 39)$ \\
\hline & 2. Jarang dibersihkan & $25 \%(10 / 39)$ \\
\hline \multirow{3}{*}{4} & Desinfeksi & \\
\hline & 1. Iya & $54 \%(22 / 39)$ \\
\hline & 2. Tidak & $46 \%(17 / 39)$ \\
\hline \multirow{3}{*}{5} & Perawatan Ternak & \\
\hline & 1. Injeksi Vitamin & $61 \%(24 / 39)$ \\
\hline & 2. Pakan Tambahan / Suplemen & $39 \%(15 / 39)$ \\
\hline \multirow{4}{*}{6} & Pengalaman Beternak Sapi Poto & \\
\hline & $1 . \leq 5$ tahun & $10,25 \%(4 / 39)$ \\
\hline & 2. $\overline{6}-20$ tahun & $33,3 \%(13 / 39)$ \\
\hline & 3. $>20$ tahun & $56,41 \%(22 / 39)$ \\
\hline \multirow{3}{*}{7} & Pekerjaan Utama sebagai Petern & \\
\hline & 1. Iya & $65,6 \%(42 / 64)$ \\
\hline & 2. Tidak & $34,3 \%(22 / 64)$ \\
\hline
\end{tabular}


Penyebab tidak terdeteksinya $T$. evansi dari pemeriksaan tersebut dipengaruhi oleh faktor eksternal dan internal (Pereira et al, 2017). Faktor eksternal berasal dari kondisi lingkungan kandang di lokasi penelitian. Kondisi tersebut ditunjukkan dalam data kuosioner, yaitu sekitar 34 dari 39 peternak atau sekitar $87 \%$ peternak di Kecamatan Cluring melakukan desinfeksi kandang dan penyemprotan insektisida serta peternak yang memperhatikan kebersihan kandang yaitu 29 dari 39 peternak atau sekitar $75 \%$, sehingga hal ini dapat menghindari vektor yang terdapat di sekitar kandang. Faktor iklim dan curah hujan mempengaruhi penyebaran vektor karena waktu pengambilan sampel dilakukan pada bulan Januari bertepatan saat musim hujan yang mendukung bagi perkembangan vektor, seperti kelembaban yang tinggi dan suhu yang ideal $32-35^{\circ} \mathrm{C}$ bagi pertumbuhan lalat dan saat musim berganti terjadi peningkatan populasi dan aktivitas lalat.

Oematan dkk (2016) menyatakan bahwa aktivitas lalat Tabanus meningkat pada musim kemarau dibandingkan pada musim hujan, selain itu Tabanus bersifat diurnal dan aktif pada kondisi lingkungan panas dengan intensitas sinar matahari yang tinggi dan periode larva lalat Tabanus membutuhkan waktu yang panjang dalam melengkapi siklus hidupnya rata-rata 1-11 minggu dengan masa hidup dewasa dapat mencapai 35 hari. Faktor eksternal selanjutnya adalah lama penyimpanan sampel.

Fahrimal dkk (2013) menyebutkan bahwa viabilitas dari $T$. evansi sangat dipengaruhi oleh waktu karena makin lama waktu tunggu dari sampel maka semakin lemah $T$. evansi. Penyebab tidak ditemukannya $T$. evansi pada seluruh sampel dapat juga diamati dari faktor internal yaitu kondisi host (Croof, et al., 2017).

Sampel darah yang diambil dari 64 ekor sapi mayoritas memiliki kesehatan yang baik. Data kuosioner menunjukkan bahwa dari 64 sampel darah sapi yang dimiliki oleh 39 orang peternak menunjukkan kondisi ternak yang sehat dengan persentase $84,3 \%$ dan sakit $15,6 \%$.. Persentase pengalaman beternak dan peternak sebagai pekerjaan utama adalah $\geq 61 \%$, sehingga peternak di Kecamatan Cluring memiliki kepedulian yang tinggi terhadap ternaknya, diantaranya dengan baiknya komunikasi peternak dan dokter hewan serta pemberian injeksi vitamin secara teratur oleh dokter hewan setempat. Faktor kekebalan tubuh merupakan faktor internal yang biasanya melibatkan faktor fisik dan biokimia, misalnya nutrisi akan mempengaruhi kekebalan host terhadap infeksi parasit (Daris, 2015).

Ternak untuk memenuhi kebutuhan hidup pokok dan kebutuhan produksinya dapat diperoleh dari kandungan air, energi, protein, mineral, dan vitamin dalam pakan (Permana, 2014). Pemberian pakan yang baik seperti yang dilakukan oleh peternak di Kecamatan Cluring dapat mengurangi risiko timbulnya penyakit Surra pada ternak disebabkan oleh pemberian injeksi vitamin dan terpenuhinya kebutuhan tersebut bagi perkembangan ternak memicu ketahanan kekebalan tubuh ternak (Pathak, 2009).

Pemeriksaan yang menunjukkan hasil negatif pada penelitian ini bisa disebabkan oleh kegagalan $T$. evansi berkembang biak akibat tidak mampu beradaptasi dalam tubuh host (Birhanu et al., 2016).

Faktor selanjutnya adalah perkembangan penyakit pada saat pengambilan sampel tersebut belum berada dalam fase parasitemia. Penyakit Surra pada sapi potong umumnya berjalan kronis sehingga masa inkubasi berjalan 3-6 bulan (Ekawasti, dkk., 2016). Parasitemia sangat tinggi variasinya selama masa infeksi, antara lain: tinggi pada awal infeksi, rendah selama infeksi berjalan kronis, dan hampir tidak ada pada hewan pembawa agen (carrier) (Ghaffar et al., 2016). Pemeriksaan laboratorium dengan kedua metode dalam penelitian ini tidak bisa selalu mendeteksi infeksi, karena tingkat parasitemia sering rendah dan berfluktuasi khususnya selama tahap kronis (Jose, 2017). Tingkat parasitemi yang fluktuatif dapat disebabkan oleh kemampuan $T$. evansi yang dapat bersembunyi di dalam kelenjar limfe dan parasit ini berada dalam aliran darah untuk mengambil glukosa darah sebagai sumber energi (Subronto, 2006). Pola parasitemia yang fluktuatif dengan ciri meningkat tajam kemudian beberapa saat 
menurun tajam bahkan hilang dari darah perifer dan kembali meningkat tajam dapat terjadi beberapa periode dalam siklus hidup T. evansi disebut sebagai pola undulating parasitemia (Subekti, dkk., 2013).

Fase perkembangan penyakit Surra dapat ditelusuri berdasarkan siklus hidup dari T. evansi dalam tubuh host. Agen T. evansi tidak melakukan perkembangan siklus hidup di dalam tubuh lalat, melainkan hanya tinggal di probosis vektor dan bertahan $\pm 6-12$ jam, kemudian ditularkan ke host melalui gigitan lalat (Rodrigues et al., 2014). Saat memasuki peredaran darah $T$. evansi segera melakukan pembelahan biner dan penderita mengalami parasitemia. T. evansi dalam siklus hidupnya hanya terdapat satu stadium. Masa inkubasi pada setiap host bervariasi, rata-rata 5-60 hari pada infeksi akut seperti pada kuda dan kerbau, sedangkan pada sapi masa inkubasi berlangsung lebih lama yaitu 3 bulan (Mekata et al., 2013). Masa inkubasi tersebut, kemudian berlanjut dalam waktu \pm 14 hari akan ditemukan parasit yang beredar dalam sirkulasi darah (parasitemia) (Garba et al., 2016). Manifestasi klinis penyakit Surra dapat berupa gejala demam berulang (intermitten) akibat parasitemia (Walden et al., 2014).

Faktor eksternal dan faktor internal adalah faktor yang saling berhubungan dalam mempengaruhi hasil penelitian ini, tidak ditemukannya $T$. evansi terutama disebabkan oleh faktor internal dan didukung oleh adanya faktor eksternal. Prevalensi penyakit Surra 0\% yang ditemukan dari hasil penelitian ini dapat pula disebabkan hewan sampel tidak terinfeksi oleh $T$. evansi, sehingga hewan sampel memang bebas dari penyakit Surra.

\section{KESIMPULAN}

Prevalensi penyakit Surra pada sapi potong adalah $0 \%$ berdasarkan hasil pemeriksaan parasitologis melalui pewarnaan giemsa dan uji MHCT, karena tidak adanya agen Trypanosoma evansi pada sampel darah yang diamati.

\section{UCAPAN TERIMA KASIH}

Peneliti mengucapkan terima kasih kepada Dinas Pertanian Kabupaten Banyuwangi atas izin yang diberikan untuk melakukan penelitian, serta pihak-pihak yang terlibat demi kelancaran penelitian ini.

\section{DAFTAR PUSTAKA}

Angara, T. E. E., Ismail, A. A., Ibrahim, A. M. 2014. An Overview on The Economic Impacts of Animal Trypanosomiasis. Glob. J. Res. Analysis., 3(7), 275-284.

Birhanu, H., Gebrehiwot, T., Goddeeris, B. M., Buscher, P., Reet, N. V. 2016. New Trypanosoma evansi Type B Isolates from Ethiopian Dromedary Camels [Research Article].

Croof, H. I. M. N., Malelle, I., Brooks, D., Abdella, H. S., Ali, N. O. M. 2017. Molecular Isolation and Characterization of Trypanosoma evansi in Dromedary Camels from Different Regions of Sudan. AASCIT. $4(6), 67-74$.

Dargantes, A. P., Mercado, R. T., Dobson, R. J., Reid, S. A. 2009. Estimating the impact of Trypanosoma evansi infection (Surra) on buffalo population dynamics in Southern Philippines Using data Cross-Sectional Surveys. Int. J. Parasitol., 39(10), 11091114.

Daris, M. 2015. Deteksi Trypanosoma evansi pada Kerbau Perah (Bubalus bubalis) di Kabupaten Enrekang [Skripsi]. Fakultas Kedokteran. Universitas Hasanuddin. Hal. 24.

Derakhshanfar, A., Mozaffari, A. A., Zadeh, A. M. 2010. An Outbreak of Trypanosomiasis (Surra) in Camels in The Southtern Fars Province of Iran : Clinical, Hematological, and Pathological Findings. RJP. 5(1), 23-26. 
Dewa, W. J. 2015. Karakterisasi Profil Protein dan Identifikasi Protein Immunogenik Isolat Trypanosoma evansi Asal Pulau Jawa [Tesis]. Fakultas Kedokteran Hewan. Universitas Gadjah Mada. Hal. 1.

Ekawasti, F., Wardhana, A. H., Sawitri, D. H., Dewi, D. A., Akbari, R. A. 2016. Serological Test for Surra Cases in Lombok Island [Proceeding of International Seminar]. Faculty of Veterinary Medicine. Bogor Agricultur University. p183-190.

Fahrimal, Y., Saad, M. D., Budiman, H. 2013. Inokulasi Trypanosoma evansi pada Mencit Mus musculus Strain BALB-C yang berasal dari Darah Sapi Lokal. J. Med. Vet., 7(2), 101-103.

Garba, U. M., Sackey, A. K. B., Lawal, A. I., Esievo, K. A. N. 2016. Dynamics of Parasitemia in Trypanosoma evansi in Donkeys and the Efficacies of Buparvaquone and Isometidium Chloride Treatmens. Science PG, 4(3), 32-38.

Gebreyohannes, M., Legesse, F. 2014. Epidemiological Study of Bovine Trypanosomiasis in Woliso Woreda, Ethiopia. J. Anim. Sci. Adv., 4(5), 833-838.

Ghaffar, M. A., Melegy, M. E., Afifi, A. F., Elaswad, B. E. D. W. 2016. The Histopthological Effects of Trypanosoma evansi on experimentally infected Mice. Men. Med. J., 29(4), 868-873.

Jose, L. 2017. Development of Diagnostic Tests of Surra Using Flagellar Antigen of Trypanosoma evansi and Its Related Monoclonal Antibody. Department of Biotechnology. Bangalore, India : Jain University.

Mekata, H., Konnai, S., Mingala, C. N., Abes, N. S., Gutierrez, C. A., Dergantes, A. P., Witola, W. H., Inoue, N., Onuma, M.,
Murata, S., Ohashi, K. 2013. Parasitol. Res. 112(4), 1513-1521.

Mufasirin, Lastuti, N. D. R., Suprihati, E., Suwanti, L. T. 2016. Buku Ajar Penyakit Protozoa Pada Hewan. Surabaya: Departemen Parasitologi Veteriner Fakultas Kedokteran Hewan Universitas Airlangga. 6-12.

Murrina. 2015. Surra. The Center for Food Security \& Public Health. United States: IOWA State University.

Oematan, A. B., Nurcahyo, R. W., Jacob, J. M. 2016. Studi Keragaman Jenis lalat penghisap darah dan Kelimpahannya di Peternakan Sapi Semi Ekstensif di Kabupaten Sumba Timur [Makalah Seminar Nasional ke 4 Fakultas Kedokteran Hewan : Universitas Nusa Cendana]. p145-151.

Pathak, A. K. 2009. Effect of Trypanosoma spp. On Nutritional Status and performance of livestock. Vet. World., 2(11), 435-438.

Pathak, K. M. L., Singh, N. 2005. Animal Trypanosomosis. INTAS POLIVET, 6(2), 194-199.

Pereira, R. M., Greco, G. M. Z., Moreira, A. M. Chagas, P. F. 2017. Applicability of plantbased products in the treatment of Trypanosoma cruzi and Trypanosoma brucei infections: a systematic review of preclinical in vivo evidence. Cambridge Core., 144(10), 1275-1287.

Permana, I. G. 2014. Kebutuhan Nutrien sesuai Jenis dan Fase Fisiologis Ternak Potong [Workshop Pelatihan Teknis Formulator Pakan Ternak Bagi Petugas]. Fakultas Petrnakan. Departemen Ilmu Nutrisi dan Teknologi Pakan. Bogor : Institut Pertanian Bogor.

Rodrigues, N. F., Junco, M. T. T., Martin, M. G., Gutierrez, C. 2014. Stomoxys calcitrans as 
possible vector of Trypanosoma evansi among camels in an affected area of the Canary Islands, Spain. Rev. Soc. Bras. Med. Trop., 47(4), 210-210.

Subekti, D. T., Sawitri, D. H., Wardhana, A. H., Suhardono. 2013. Pola Parasitemia dan Kematian Mencit yang Diinfeksi Trypanosoma evansi Isolat Indonesia. Balai Besar Penelitian Veteriner Bogor. 18(4), 274-290.

Subronto. 2006. Penyakit Infeksi Parasit \& Mikroba pada Anjing \& Kucing. Yogyakarta: Gadjah Mada University Press.
Sugiyanto, B. 2017. Laporan Penyakit dengan Tanda Umum bulan Januari-Maret 2017 Kabupaten Banyuwangi. Bidang Keswan dan Kesmavet. Dinas Pertanian Kabupaten Banyuwangi.

Walden, H. S., Ness, S. A. L., Mittel, L. D., Divers, T. J., Laaren, K. V., Sellon, D. C. 2014. Chapter 60 : Miscellaneous Parasitic Desease. Florida : ELSEVIER.

Yadav, S. C., Kumar, J., Gupta, A. K., Jerome, A., Kumar, P., Kumar, R., Tehri, K., Kumar, R. 2016. Parasitological, Biochemical, and Clinical Observations in Ponies Experimentally Infected with Trypanosoma evansi. JEBAS. 4(Spl-4-EHIDZ), 144-150. 